\title{
Pelatihan Bahasa Inggris Untuk Siswa-Siswi di TK Melati Indah Sayang-Sayang Cakranegara Mataram
}

\author{
Kamarudin ${ }^{1}$, Tawali $^{2}$ \\ ${ }^{12}$ Program Studi Pendidikan Bahasa Inggris FBMB UNDIKMA \\ Corresponding Author: kamarudin@undikma.ac.id
}

\begin{abstract}
Community service is the implementation of knowledge gained in schools, or lecturing process formally or informally. This community service aimed at giving English language training towards students of TK Melati Indah Sayang-Sayang, Cakranegara Mataram. This community service used lecturing, practice, and discussion. The respondents consisted of 30 students. The result of the training concluded that English language training towards students of TK Melati Indah Sayang-Sayang, Cakranegara Mataram was successful. It is proved from the students' enthusiasm within the process of the training and their learning achievement after giving the training. Thus, the training of English language to the students is highly important especially in TK Melati Indah Sayang-Sayang as they will be the agent of change and future generation who will acquire English language well. Through this training, students of TK Melati Indah Sayang-Sayang are expected to have knowledge and basic experience to communicate through English language as their foundation and motivation to develop their skill.
\end{abstract}

Keywords: English Language Training, Students of TK of Melati Indah

Abstrak. Pengabdian kepada masyarakat merupakan bentuk implementasi dari ilmu yang sudah diperoleh di sekolah, maupun perkuliahan secara formal maupun informal. Pengabdian kepada masyarakat ini bertujuan untuk memberikan pelatihan bahasa Inggris untuk anak-anak di TK Melati Indah Sayang-Sayang Cakranegara Mataram. Pengabdian ini menggunakan metode ceramah, praktik dan diskusi. Adapun responden yang terlibat yaitu sebanyak 30 siswa. Dari hasil pelatihan yang diberikan, dapat disimpulan bahwa pelatihan bahasa Inggris untuk anak-anak di TK Melati Indah SayangSayang dapat dikatakan sukses meskipun terdapat beberapa kendala nonteknis. Hal tersebut bisa dilihat dari antusiasme belajar para peserta pelatihan dan hasil belajar mereka setelah diberikan pelatihan. Oleh karena itu, pelatihan bahasa Inggris untuk anak-anak khususnya di tingkat TK sangat penting sebagai agen perubahan serta genenerasi penerus masa depan yang mampu menguasai Bahasa Inggris dengan baik dan benar. Dengan adanya pelatihan ini juga, anak-anak khususnya di TK Melati Indah Sayang-Sayang diharapkan memiliki wawasan dan pengalaman dasar bahasa Inggris dalam melakukan komunikasi bahasa Inggris sebagai fondasi sehingga menjadi motivasi untuk dapat mengembangkan kemampuan mereka kedepannya.

Kata Kunci: Pelatihan Bahasa Inggris, Siswa-Siswi TK Melati Indah

\section{PENDAHULUAN}

Belakangan ini bahasa Inggris tidak hanya diajarkan di tingkat SMP, SMA maupun perguruan tinggi melainkan sudah mulai diajarkan sejak dini berawal dari tingkat SD sampai perguruan tinggi bahkan sejak masih di tingkat PAUD dan TK. Maka wajarlah kemudian pemerintah memasukkan bahasa Inggris untuk dijadikan sebagai mata pelajaran wajib mulai dari tingkat TK sampai seterusnya. Jadi, bahasa Inggris memiliki peranan yang sangat penting dalam kehidupan sehari-hari. Selain digunakan untuk kebutuhan sehari-hari, bahasa Inggris juga digunakan sebagai bahasa standar penerbangan internasional, tujuan pendidikan, pekerjaan, hiburan, dan komunikasi elektronik. Kemanapun manusia pergi di seluruh belahan dunia selalu dihadapkan pada penggunaan bahasa Inggris. Hal ini membuktikan bahwa bahasa Inggris menjadi bahasa komunikasi Internasional.

Bahkan ada yang menyebutkan bahwa bahasa Inggris adalah bahasa yang digunakan orang di negara Amerika Serikat, Australia, Afrika Selatan, Inggris, Irlandia Utara, Kanada, Selandia Baru serta beberapa negara lainnya dengan jumlah pengguna antara 350 sampai 375 juta orang. Oleh karena itu, bahasa Inggris adalah bahasa yang telah banyak digunakan oleh beratus-ratus juta orang di dunia. Bahasa Inggris, menjadi sangat penting disemua lini kehidupan. Sebagai bahasa internasional, ia digunakan sebagi sarana komunikasi di sektor ekonomi, sosial politik, budaya dan lain lain antara negeri 
satu dengan yang lain. Begitu juga wisatawan atau turis yang mengunjungi negara lain, bahasa Inggris menjadi bahasa yang menjembatani transfer informasi dan komunikasi dengan orang orang setempat dinegeri yang dikunjunginya.

Oleh sebab itu, mau tidak mau kita harus sadar bahwa begitu pentingnya bahasa Inggris untuk generasi kita yang akan datang. Melalui kegiatan ini maka diharapkan nantinya akan mampu memberikan sedikit masukan dan persiapan untuk menuju generasi yang siap bersaing dengan menguasai dasar-dasar Bahasa Inggris untuk komunikasi sehari-hari. Pelatihan bahasa Inggris untuk anak-anak di TK Melati Indah yang berada di Sayang-Sayang Cakranegara Mataram sangat perlu diberikan sebagai wadah bagi para dosen untuk mengabdikan diri dalam melaksanakan salah satu kewajiban tridharma perguruan tinggi sebagaimana yang dituangkan dalam Undang-undang Nomor 12 Tahun 2012 tentang Pendidikan Tinggi Pasal 45 bahwa pengabdian kepada masyarakat merupakan kegiatan sivitas akademika dalam mengamalkan dan membudayakan ilmu pengetahuan dan teknologi untuk memajukan kesejahteraan umum dan mencerdaskan kehidupan bangsa. Diharapkan dengan adanya pelatihan ini, para generasi pemula khususnya anak-anak yang tengah menempuh pendidikan di tingkat TK Melati Indah yang berada di Sayang-Sayang Cakranegara Mataram memiliki wawasan dan pengalaman dasar serta kesiapan dalam melakukan komunikasi dalam bahasa Inggris sehingga menjadi motivasi untuk dapat mengembangkan kemampuan mereka kedepannya.

\section{METODE PELAKSANAAN}

Guna suksesnya rangkaian kegiatan yang ingin dilaksanakan, maka sangat diperlukan sebuah metode dengan tujuan kegiatan tersebut dapat bejalan dengan baik dan lancar. Selain itu salah satu dampak positif dari penerapan metode dan/atau pendekatan dalam suatu kegiatan yaitu dapat terlaksananya rangkaian kegiatan yang telah dirancang secara maksimal dan terarah. Maka hal tersebut menjadi landasan utama dalam kegiatan masayarakat ini untuk menentukan metode dalam melaksanakan program pelatihan. Ada 3 metode dan tahapan pelaksanaan yang akan diterapkan dalam program pelatihan ini yaitu antara lain:

a. Ceramah, yaitu penyampaian materi secara langsung kepada peserta pelatihan oleh narasumber agar supaya para peserta dapat mengetahui dan menyerap gambaran umum tentang materi pelatihan yang disampaikan selama proses pelatihan dilaksanakan.

b. Praktik, yaitu memberikan kesempatan bagi para peserta untuk memperaktikkan materi yang disampaikan selama proses pelatihan berlangsung meliputi materi dasar pelatihan dan interaksi lansung dengan peserta menggunakan bahasa Inggris dasar yang telah disiapkan.

c. Diskusi dan tanya jawab, yaitu memeberikan kesempatan bagi para peserta untuk bertanya serta menyampaikan permasalahan seputar mengenai hambatan atau keluhan yang dialami selama pelatihan diberikan yang telah disampaikan dan diperaktikkan.

\section{HASIL PENGABDIAN DAN PEMBAHASAN}

Dalam pengabdian ini, ada empat (4) tahap pelaksanaan kegiatan yang di implementasikan yaitu; Perencanaan dan koordinasi, tindakan, pendampingan, serta refleksi dan evaluasi. Berikut di uraikan detail kegiatan pada setiap tahapan.

Kegiatan pengabdian dilaksanakan dengan tatap muka dan praktek ini berjalan dengan baik dan lancar sebagaimana yang diharapkan, tentunya tetap mengedepankan protokoler yang ada. Pertemuan tatap muka dilaksanakan dengan metode drilling/training yang kemudian dilanjutkan dengan praktek real communication.

\section{Perencanaan dan Koordinasi}

Kegiatan pada tahapan perencanaan dan koordinasi terdiri dari; a), penyusunan program pelatihan, b) sosialisasi program, dan c) koordinasi dengan pihak-pihak terkait. Penyusunan program 
dilakukan berdasarkan jangka waktu kegiatan dan jumlah peserta. Materi pembelajaran di PKM ini disesuaikan dengan tema kegiatan yaitu Bahasa Inggris untuk siswa/I tingkat TK.

\section{Tindakan}

Pada tahap tindakan, ada tiga kegiatan yang telah dilaksanakan yaitu; a) pembentukan kelompok peserta pelatihan, b) pemberian materi, dan c) pengaplikasian materi. Kelompok dibentuk berdasarkan kemampuan masing-masing peserta yang dimana mereka terlebih dahulu diberikan placeman test.

Setelah kelompok terbentuk, mereka diberikan materi Bahasa Inggris dasar untuk TK yang konteksnya sesuai dengan level mereka. Dalam pembelajaran, setelah mereka menerima teori, mereka diminta untuk mempraktekkan materi dengan cara menyebutkan nama-nama benda dalam Bahasa Inggris. Dari Tindakan ini, mereka terlihat sangat antusias dalam mempraktikkan materi yang diberikan terbukti dengan $90 \%$ dari mereka dapat menjawab pertanyaan yang diberikan.

Berikut foto pelaksanaan program PKM yang telah dilaksanakan.
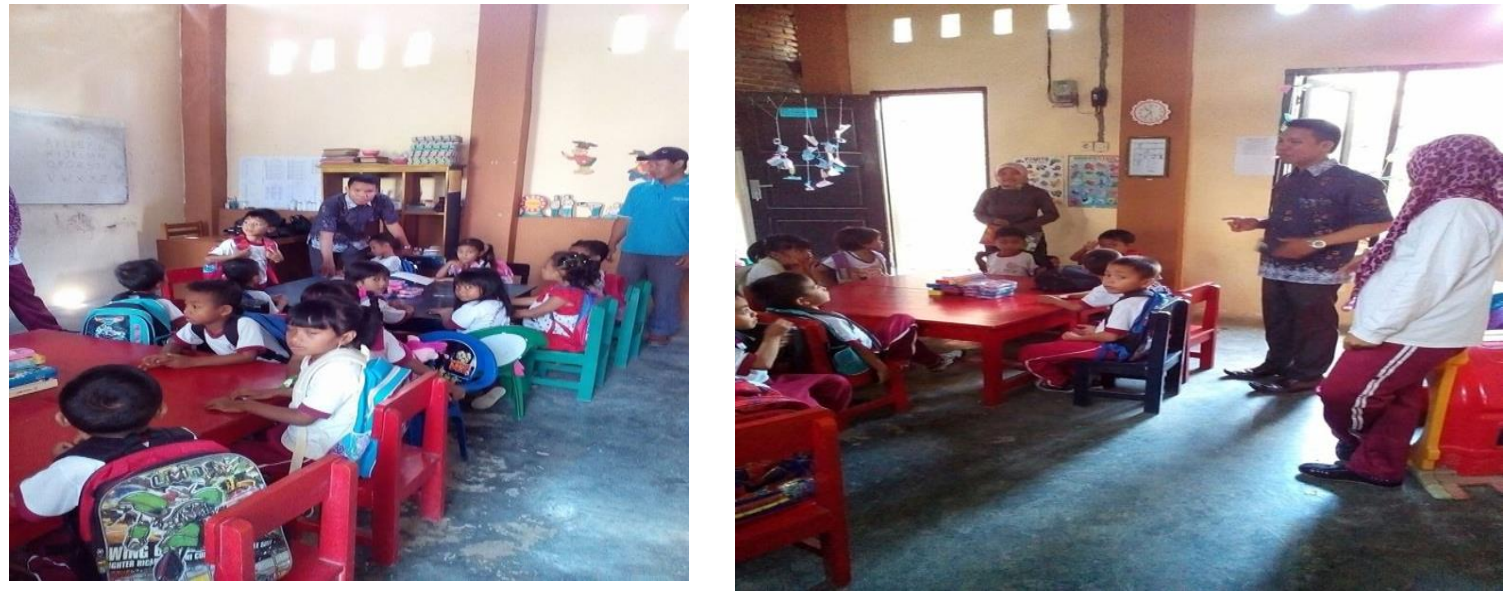

\section{Pendampingan}

Pada tahap pendampingan, pelatih akan memberikan pelatihan pada tahap selajutnya jika memungkinkan. Tahapan ini merupakan kegiatan pasca program PKM. Tim yang dibantu oleh guruguru yang ada di TK Melati Indah Sayang-Sayang akan terus melakukan pendampingan sampai peserta bisa mempraktikkan materi yang telah mereka terima.

\section{Refleksidan Evaluasi}

Pada tahapan refleksi dan evaluasi bertujuan untuk meningkatkan kualitas dan sekaligus mempelajari kelebihan dan kelemahan dari program yang telah dilaksanakan yang nantinya dapat digunakan sebagai acuan untuk program-program selanjutnya. Adapun evaluasi dilaksanakan berdasarkan hasil dari pelatihan yang diberikan. Pemantauan dan evaluasi dilaksanakan juga pada saat pelatihan dilaksanakan. Secara umum para peserta mengatakan pelatihan ini sangat baik dan materi yang diberikan merupakan materi yang sangat dibutuhkan untuk anak-anak di tingkat TK.

\section{KESIMPULAN DAN SARAN}

Dari hasil pelatihan yang diberikan kepada siswa-siswi di TK Melati Indah Sayang-Sayang Cakranegara Mataram dapat dikatakan sukses. Hal ini bisa dilihat dari antusiasme belajar para peserta dengan mampu menyebutkan nama-nama benda disekitar mereka dengan menggunakan Bahasa Inggris, bahkan guru-guru yang ada di tempat tersbut meminta untuk melaksanakan pelatihan serupa dipertumuan selanjutnya. 
Dengan adanya program pemberdayaan masyarakat melalui pelatihan Bahasa Inggris siswa-siswi di TK Melati Indah Sayang-Sayang Cakranegara Mataram diharapkan mampu meningkatkan pengetahuan mereka.

\section{DAFTAR PUSTAKA}

Asep Sopian. (2012) Training Penyuluhan Keagamaan di Kabupaten Subang. Kampus Purwakarta. Dira Permana, Siti,S.Q, Muhammad Arief R. (2020) Pelatihan Keterampilan Berkomunikasi Bahasa Inggris Bagi Pramusaji Kedai di Kawasan Wisata Aik Berik. Jurnal Pengabdian Undikma: Jurnal Hasil Pengabdian dan Pemberdayaan Kepada Masyarakat, Mei 2020. Vol. 1., No. I eISSN: 2722-5097 Pg.: 1-7

Miskin di Kota Yogyakarta. Universitas Negeri Yogyakarta.

Penny Rahmawaty, et al. (2012) Pemberdayaan Usaha Ekonomi Produktif bagi Masyarakat Tim. (2013) Panduan Pelaksanaan Penelitian dan Pengabdian Kepada Masyarakat di Perguruan Tinggi Edisi IX. Direktorat Jenderal Pendidikan Tinggi Kementerian Pendidikan dan Kebudayaan.

Tim. (2016) Panduan Pelaksanaan Penelitian dan Pengabdian Kepada Masyarakat di Perguruan Tinggi Edisi X. Direktorat Jenderal Pendidikan Tinggi Kementerian Pendidikan dan Kebudayaan. 